\title{
Research in Progress
}

TESOL/AAAL Joint Colloquium on 'Plurilingualism and Language Education: Opportunities and Challenges', held at the 2014 AAAL Conference Portland Oregon, USA.

This colloquium was organized by Ryuko Kubota (University of British Columbia, Canada) and Sue Garton (Aston University, UK) as part of the collaboration between the American Association for Applied Linguistics and TESOL International Association.

The starting point for the session was the recognition that, although plurilingualism has increasingly been discussed in language education, the dominance of English poses challenges as well as opportunities. Although multilingualism as a sociolinguistic phenomenon has pervaded local communities due to the global mobility of people, the dominance of English in language education policy worldwide poses a significant challenge in promoting plurilingualism in formal education. At the same time, pluralingualism, envisioned as an educational goal, offers applied linguists an opportunity to rethink the ways in which the acquisition of additional languages is theorized. The colloquium invited presenters to discuss the definition, significance, application, opportunities, and challenges of plurilingualism from the diverse perspectives of sociolinguistics, SLA, and classroom research.

Four presenters were invited from both Europe and North America: Shelley Taylor (Western University, Canada), Jasone Cenoz, (University of the Basque Country UPV/EHU, Spain), Diane Larsen Freeman, (University of Michigan/University of 
Pennsylvania, USA) and Constant Leung (King's College London, UK).

A number of common themes emerged across the talks. These included:

1. There is a need for conceptual clarity, with a multitude of terms currently being used without a clear distinction or definition. Thus we find plurilingualism, multilingualism, the multilingual turn, translanguaging and so on.

2. Plurilingualism should be viewed as dynamic, fluid and socially situated. As Shelly Taylor explained it, plurilingualism refers to the competences individuals develop in a number of languages from desire or necessity to meet communicative needs at given points of time.

3. Learners' plurilingual funds of knowledge or linguistic repertoires are often ignored and this can have an effect on their academic achievement.

4. There is need for what speakers defined as a paradigm shift in language education in order to get away from traditional monolingual or monoglossic (Garcia, 2009) instructional assumptions.

Shelley Taylor was the first presenter with her talk on 'Plurilingualism in the Eye of the Beholder'. She underlined how plurilingualism can mean different things to different people. To researchers plurilingualism may seem part of a zeitgeist which may partially be explained in terms of the inadequacy of long-accepted models and concepts in the fields of bilingualism and bilingual education to account for situations of extreme linguistic complexity in settings such as Nepal and India (Taylor, 2014; Taylor and Snodden, 2013), but also in Western countries experiencing unprecedented levels of variation in individual linguistic repertoires (or "superdiversity") due to globalization and migration.

For super-diverse learners, on the other hand, varied linguistic repertoires may just 
seem 'how it is', with plurilingualism as legitimate language in a holistic view of super diverse lives.

Finally, from the point of view of practitioners, plurilingualism may require a paradigm shift. Teachers' beliefs around plurilingualism are often based on monolingual instructional assumptions and they may display resistance to the notion of plurilingualism.

Taylor went on to define plurilingual pedagogy as a pedagogy that provides space for plurilinguals to draw on diverse linguistic competences, heightened multilingual awareness, discursive and pragmatic knowledge of other learners and their overall “funds of knowledge" (Moll \& González 1997). She identified areas for future research in order to promote a paradigm shift:

- Conduct collaborative inquiry with educators to co-develop context-sensitive practices that work for them and that lead them to believe that plurilingual practices are 'good teaching.'

- Work with educators so they may see that plurilingual practices are necessary; no more expendable ("irrelevant") than culturally-responsive teaching (Gay, 2002).

- Reveal students' linguistic repertoires masked in the absence of plurilingual pedagogy and recognize their superdiverse voices

- Develop and disseminate plurilingual pedagogical materials to provide scaffolding to teachers undertaking a paradigm shift.

Jasone Cenoz's talk was entitled 'English and Other Languages in European Plurilingual Education'. She discussed two different conceptualizations that can be 
found in education: a monolingual approach based on language separation and a plurilingual approach based on the interaction between the languages in the learner's linguistic repertoire. In Europe, while the majority of children going to school have several languages in the curriculum, there is still a monolingual approach which can be seen in the teaching of English as a second or additional language and which tries to isolate the learning of English from the influence of other languages because language interaction is seen as negative.

The plurilingual approach, on the other hand, needs to take into account the whole linguistic repertoire of multilingual speakers and the social context (Cenoz \& Gorter, 2011, 2013). Cenoz cited her study based on survey data from the Institute for Evaluation and Research in the Basque Country which showed that competence in one skill such as writing correlates more closely across the three languages of Basque, Spanish and English than competence across skills in the same language. Pedagogically, multilingual speakers can therefore benefit from the affordances given by their linguistic repertoires. However, in situations of minority languages at risk, the promotion of flexible language arrangements/translanguaging could encourage focus on majority language.

The third speaker was Constant Leung, who took a more specific approach in his talk on 'Modeling Plurilingual Competence'. Leung's starting point was the Common European Framework of Reference for Languages (CEFR, Council of Europe, 2001), which has been adopted widely by education authorities internationally. The CEFR has three components of communicative language competence- linguistic, sociolinguistic and pragmatic. However, the CEFR sees languages as bounded entities and does not takes account of language use that involves more than one language. 
Thus it represents a particular (and restricted) view of language knowledge and language use that does not correspond to many actual instances of language communication. Leung used a number of examples, drawn from the current literature on translingualism and his own research data collected in linguistically diverse classrooms, to show how linguistic competence is not independent of use; sociocultural conditions are situated and pragmatics have to be locally negotiated. The CEFR competence descriptors are ill-equipped to capture the dynamic and contingent nature of language use. It is necessary to move from conceptualising language as a static normative system (in terms of lexico-grammar and rules of use) to an emergent process of sense-making that makes use of locally available communication resources fluidly and to see language use as part of situated social practice.

Diane Larsen-Freeman was the final speaker with her paper on 'Plurilingualism: Challenging Assumptions'. She focused on plurilingualism as an opportunity to challenge some assumptions in SLA with the problematization of 'second', 'language' and 'acquisition'.

Second is problematic because it dichotomizes L1/L2 and it suggests consecutive acquisition, which is not the reality. It is also problematic when used to mean the language of the environment as in second, as opposed to foreign, for example the heterogeneous identity of Spanish in the United States (Larsen-Freeman \& Freeman, 2008). Larsen-Freeman suggested therefore that the term Plurilingual could be used instead of Second.

Language is also problematic because it has meant linguistic units and when language 
is perceived to be a closed system, a fixed target, then language learners are disadvantaged to a certain extent as their language will always be judged as deficient in some sense. Therefore, language needs to be reconceived non-atomistically, as a complex dynamic system, for example (Larsen-Freeman, 1997).

Acquisition implies language is a commodity and it implies there is an endpoint and that completion is possible. On the other hand, development is never complete. Larsen-Freeman concluded by proposing a shift from Second Language Acquisition to Plurlilingual or Multilingual Development, which has a number of implications:

- A shift from a focus of the acquisition of stable structures of linguistic form to plurilingual development in existing communities of practice

- A focus on learners' ability to adapt and their ability to exploit the potential to make meaning

- A shift from seeing fossilization as permanent cessation to an indefinite stabilization or perhaps development in other ways (See, e.g., Berdan, 1996).

- Looking at what learners are doing from the learners' point of view (self-referential) (Ortega, 2014)

Larsen-Freeman concluded that plurilingualism has been helpful to the SLA community because it forces a reconsideration of assumptions and provides us with a new set of questions to address (e.g., Pavlenko, 2014).

However, a profound a shift will take time. Moreover, caution should be used in relation to the uncritical acceptance of plurilingualism in TESOL (Flores, 2013, p. 501; Kubota in press), lest it promote the same neoliberal agenda it seeks to resist.

\section{References}


Berdan. R. (1986). Disentangling language acquisition from language variation. In R. Bayley \& D. Preston (Eds.), Second language acquisition and linguistic variation (pp. 203-244). Amsterdam/Philadelphia: John Benjamins.

Cenoz, J., \& Gorter, D. (2011). Focus on multilingualism: A study of trilingual writing. The Modern Language Journal 95: 356-369.

Cenoz, J. \& Gorter, D. (2013) Towards a plurilingual approach in English language teaching: Softening the boundaries between languages. TESOL Quarterly 47: 591-599.

Council of Europe. (2001). Common European framework of reference for language learning and teaching. Cambridge, UK: Cambridge University Press.

Flores, N. (2013). The unexamined relationship between neoliberalism and plurilingualism: A cautionary tale. TESOL Quarterly 47: 500-520.

García, O. (2009). Bilingual education in the $21^{\text {st }}$ century: A global perspective. West Sussex: Wiley-Blackwell.

Gay, G. (2002). Preparing for culturally responsive teaching. Journal of Teacher Education, 53(2), 106-116.

Kubota, R. (in press). The multi/plural turn, postcolonial theory, and neoliberal multiculturalism: Complicities and implications for applied linguistics. Applied Linguistics. http://applij.oxfordjournals.org/content/early/2014/08/13/applin.amu045.full.p $\underline{\text { df?keytype }=\text { ref\&ijkey }=\text { fh8GX7UJ2zNdIPB }}$

Larsen-Freeman, D. (1997). Chaos/Complexity science and second language acquisition. Applied Linguistics 81: 141-165.

Larsen-Freeman, D., \& Freeman, D. (2008). Language moves: The place of "foreign" languages in classroom teaching and learning. Review of Research in Education 32: 147-186. 
Moll, L. C., \& Gonzalez, N. (1997). Teachers as social scientists: Learning about culture from household research. Race, ethnicity, and multiculturalism: Policy and practice, 89-114.

Ortega, L. (2014). Ways forward for a bi/multilingual turn in SLA. In S. May (Ed.), The multilingual turn. Implications for SLA, TESOL and bilingual education (pp. 32-53). New York \& London: Routledge.

Pavlenko, A. (2014). The bilingual mind. New York: Cambridge University Press.

Taylor, S. K. (2014). From 'monolingual' multilingual classrooms to 'multilingual' multilingual classrooms: Managing cultural and linguistic diversity in the Nepali educational system. In D. Little, C. Leung \& P. Van Avermaet (Eds.), Managing diversity in education: key issues and some responses (pp. 259-274). Clevedon, UK: Multilingual Matters.

Taylor, S. K., \& Snoddon, K. (2013). Plurilingualism in TESOL: Promising controversies. TESOL Quarterly, 47(3), 439-445. Doi: 10.1002/tesq.127 